\title{
MARIA BOUCHER MOVILA'S WRITING: GENDER AND AUTHORSHIP
}

\author{
L'EUVRE DE MARIA BOUCHER MOVILĂ : \\ GENRE ET AUCTORIALITÉ
}

\author{
Ramona MIHĂIL $\breve{A}^{1}$ \\ https://doi.org/10.52744/9786062613242.04
}

\begin{abstract}
The true identity of the author of the novel Omul muntelui (The Man of the Mountain) (1858), signed by the pseudonym Doamna L. (Lady L.), is not known with certainty. In the 196os, serious research was carried out on this question, which posited three potential authors of this work: C.A. Rosetti, Maria Boucher Movilă or V.A. Urechia. Following clues suggesting authorship by Movilă, many now believe that she was the first woman to have written a novel in the Romanian language. In 2013, the novel Omul muntelui (The Man of the Mountain), as well as the short story Amelie Ştefănescu (signed Doamna Maria L, and therefore probably written by the same person) were republished by the Museum of Romanian Literature, in Cyrillic writing (in which the original version was published), but in a Romanian version modernized under the supervision of Ramona Mihăilă.
\end{abstract}

Keywords: Maria Boucher Movilă; Women writers; Authorship; Nineteenth century

Résumé : La véritable identité de l'auteur ou de l'autrice du roman Omul muntelui (L'homme de la montagne) (1858), signé du pseudonyme Doamna L. (Mme L.), n'a encore jamais pu être dévoilée avec certitude. Dans les années 1960, des recherches sérieuses ont été menées. Elles ont conduit à prendre en considération trois auteurs et autrices potentiels de cette ouvre : C.A. Rosetti, Maria Boucher Movilă ou V.A. Urechia. Suivre les indices en faveur de l'auctorialité de Maria Boucher Movilă, c'est lui donner la primeur d'être la première femme à avoir écrit un roman en langue roumaine. En 2013, le roman L'homme de la montagne, de même que la nouvelle Amelie Ștefănescu (signée Doamna Maria L, Mme Maria L, donc vraisemblablement écrite par la même personne) ont été republiés aux éditions du Musée de la Littérature Roumaine en écriture cyrillique (comme dans la version originale), mais dans une version roumaine modernisée par les bons soins de Ramona Mihăilă.

Mots-clés: Maria Boucher Movilă; Femmes écrivains; Auctorialité; XIXe siècle

${ }^{1}$ Professor, PhD. at Dimitrie Cantemir Christian University, ramona.mihaila@ucdc.ro 
The latter half of the nineteenth century in the Romanian Principalities was a time of singular change and emancipation for women regarding their political engagement, legal status, access to higher education, and involvement in professional and public life. In addition, their visibility in the professional world of writing (as writers, translators, journalists, columnists, travel reporters) enabled them to start forging a tradition of their own.

It seems that the first novel written by a woman was the one published under the pseudonym Doamna L (Lady L), Omul muntelui (Man of the Mountain) (1858). In the 1960 s debates occurred concerning the authorship of this novel: some critics attributing it to the writer Vasile Urechia (1834-1901), others to the French-born writer Maria Boucher Movilă (1820-1870), and yet others who concluded that both of these authors wrote the novel and chose a pen name to conceal this. It is assumed that Vasile Urechia, along with Maria Boucher Movilă, wrote the short story "Amelie Stefanesco", signed also with a pen name, Doamna Maria L. (Lady Maria L.) and published in installments in the newspaper "Zimbrul şi Vulturul" ("The Buffalo and the Eagle"), in 1858. A later novel in French, Les Sept montagnes, histoire moldave, was signed Marie Movilă and published in Paris in 1863.

These researches suggest that it is increasingly likely that the pseudonym Lady L. hides the name of Marie Boucher Movilă. Many Romanian women writers at that time used a pen name to sign their writings: Princess Elena Ghica (Dora d'Istria), Smara (Smaranda Gheorghiu), Constanța Dunca-Schiau (Camille d'Alb or E.D. Albon), Emilia Lungu (Bănățeanul Moş, Bănățeanul Călător sau Bănățeanul June) etc. We will explore the basis of this presumption below.

\section{Rise of women writers in the Romanian Principalities}

In his essay "Women at the Foundation of Romanian Literary Culture. From Muse to Writing Agent” ${ }^{2}$, Marcel Corniş-Pope asserts that

among the earliest fiction writers was "Lady L." (probably Marie Boucher in collaboration with V.A. Urechia), author of the romance Omul muntelui (Man of the Mountain) (1857-1858) [...]. The novel recounts the story of a semi-autobiographical character Matilda, an orphaned French girl brought up in a monastery and then hired as a governess by a boyar family in Moldavia. Matilda falls in love with her adoptive country, which she explores during a succession of trips with a mysterious "man of the mountain" who turns out to be a banished political revolutionary. Beyond its

${ }^{2}$ Included in Volume IV of "Types and Stereotypes" of Marcel Corniş-Pope and John Neubauer (ed.). History of the Literary Cultures of East-Central Europe: Junctures and Disjunctures in the 19th and 2oth Centuries, John Benjamin Publishing Company, 2004, 231. 
sentimental plot, this romance offered an accurate representation of early nineteenth-century Moldavian social life. (Corniş-Pope 2004, 231)

Omul muntelui (Man of the Mountain) was not only the first novel to be signed by a woman, but also one of the first serialized novels of Romanian literature. It initially appeared in a column of the newspaper Românul (The Romanian, I, 1857, no. 1-37, II, 1858, no. 3-19), a political and cultural newspaper published in Bucharest from 1857 to 1905, and run by Constantin Alexandru Rosetti, one of the leaders of the 1848 Revolution in Wallachia. Note that at the time Omul muntelui (Man of the Mountain) was published in installments, two other women contributed to the newspaper, Maria Rosetti and Sofia Cocea.

Maria Rosetti (1819-1893), née Grant in the Channel Islands but established mainly in Bucharest from 1837 on (first as a private teacher, then as the spouse of the politician and journalist C. A. Rosetti), initiated the journal Mama şi copilul (The Mother and Child) for which she wrote most of the articles and translated Madame de Genlis' Zuma ou la découverte du quinquina, suivi de la belle Paule, de Zénéide, et des roseaux du Tibre (1866) into Romanian. She was deeply involved in the revolutionary events of 1848, supporting her husband. Her patriotic deeds were praised in foreign journals such as Le Courrier français (issue 304, Dec. 1848) and later, in 1851, Jules Michelet published the work Les Principautés Danubiennes. Madame Rosetti. 1848, in Evenement, Paris.

As to the Moldavian unionist Sofia Cocea (1839-1861), she had already translated in 1852 , when she was only 13 years old, Madame de Genlis' novel Palmyre et Flaminie ou Le Secret (1821), into Palminia şi Flaminia sau Secretul. She also wrote articles for the unionist journals Tribuna (The Tribune), Reforma (The Reform), Gazeta poporului (The Gazette of People), Zimbrul (The Buffalo), Foiletonul Zimbrului (The Wisent's Column), Românul (The Romanian), Dacia, Steaua Dunării (The Danube's Star), Gazeta de Moldavia (The Gazette of Moldavia). In her articles she tackled many aspects of the social life: the education and the national culture as well as the role of women in society, female births out of wedlock, peasant hardships, or the foreign affairs of the Romanian Principalities.

\section{muntelui \\ 2. State of research about the authorship of Omul}

Reflecting the research on authorship of the 1960's referred to above, the authors of Dicționar cronologic al romanului românesc de la origini până la 1989 (Chronological Dictionary of the Romanian novel from its origins until 1989, 2004), observed that Omul muntelui (Man of the Mountain) "is among the first attempts of the genre in Romania. It 


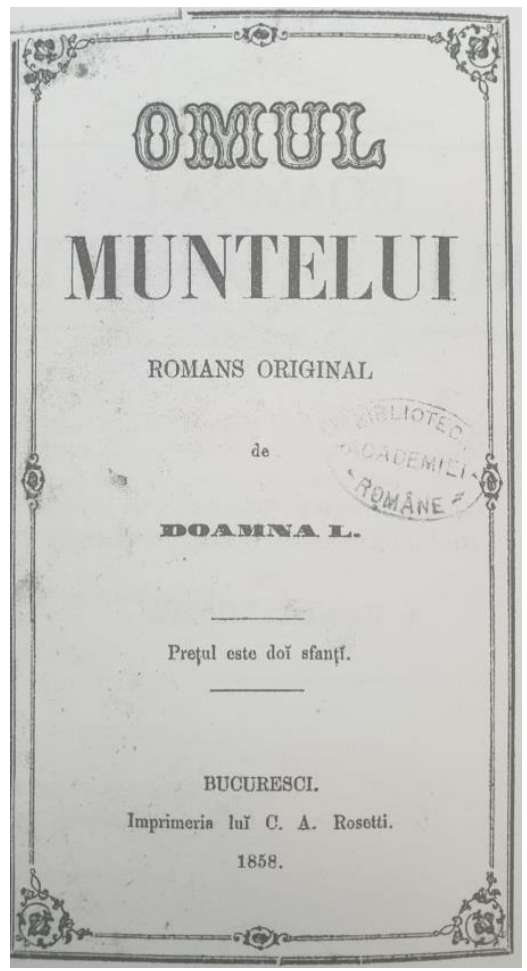

challenged numerous and varied investigations in connection with the deciphering of "the mystery of Doamna L. (Lady L.).” The literary critics who took part in the discussions (Dimitrie Păcurariu, Ştefan Cazimir, Paul Cornea) attributed, one by one, the paternity of the novel to Constantin Alexandru Rosetti, Maria Boucher (a French writer based in the Romanian Principalities) and, ultimately, to her collaboration with Vasile Alexandrescu Urechia."(Istrate et al 2004, 112)

Nicolae Manolescu, in his book Arca lui Noe (Noa's Ark), states that this novel is a work written by Marie Boucher Movilă in collaboration with V.A. Urechiă and considers that Movilă took the greater part in the novel's composition mentioning as arguments both the author's inclination towards French literature as influenced by Balzac, and the fact that he considers Urechiă incapable of writing this novel only by himself. Manolescu thinks that Movilă wrote the novel in French, and that Urechiă translated it into Romanian:

Here, before the novel Elena (...) we are talking about the analytical style of our future psychological novel (Duiliu Zamfirescu), but in 1858 no other post-revolutionary novelist could have conceived such a work. Nicolae Filimon's Ciocoii vechi şi noi (Old and New Upstarts) is well below this level of understanding of the sentimental matters. In the novel Omul muntelui (Man of the Mountain), with all the clichés of the rising popular romanticism (especially those descriptions related to the always explicit language of eyes or gestures, or those generally coming from the authors' too obvious habit to anticipate reactions) we are still close to the ideology and symbols of an Alecu Russo. (Manolescu 1990, 316)

The plot of the novel is centered on Matilda, a French governess who came to Romania to a family of boyars from Iaşi, for their daughter, Rocsandra. Matilda falls in love with Mionescu, a young poet from a noble family, but without any wealth. Although he loves her, after two years, Mionescu chooses to leave Matilda, who, brokenhearted, will leave the boyar's house to find her soul relief in the mountains, starting hiking Mountain Ceahlău and its surroundings. Here he meets the Mountain Man, named Hora, a revolutionary and outlaw, who lives among peasants and shepherds and talk to them "about their past, their rights, their 
suffering." They meet in several circumstances and the 'mountain man' saves her life three times. The end of the book is a romantic one, so, after a one-year exile imposed by Matilda, the two get married on a day of great religious celebration, Saint Mary.

\section{Place of action in Omul muntelui and its peculiarities (Ceahlău)}

Mountain Ceahlău is a place often mentioned by writers, tourists or simple passers-by. It has been widely described by locals, Romanian scholars and foreigners alike. The mountain has inspired numerous stories, legends, short stories, novels, travel notes, drawings, sketches, paintings, poetry and specialized articles. Emil Juncănaru Pedemonte observers that "starting with the 17th century, the writings about Ceahlău multiplied. A first description with many references is made by the ruler Dimitrie Cantemir in Descriptio Moldavie.” (Juncănaru Pedemonte 2013, 119)

Other references to Ceahlău are also provided by many writers, e.g. Marco Baldini, Iosif Solomon Del Medigo, Alexandre Dumas, Gheorghe Asachi, Alecu Russo, Vasile Alecsandri, J.A. Vaillant, William de Kotzebue. There were also women writers influenced by the legends about Ceahlău Mountain: Movilă, besides Omul muntelui (The Man of the Mountain), used these legends as well in Loupo, and the English writer and painter Marie Adelaide Walker (1873-1927), who talked about the monasteries in Moldavia in the last chapters of her book, Eastern Life and Scenery: with Excursions in Asia Minor, Mytilene, Crete, and Roumania (1886), refers to them too. Only two years later, Walker wrote another book, Untrodden Paths in Roumania, as a result of her travels across Romania and in which she wrote of the country's religious beliefs and customs, historical or imaginary facts, legends and traditions.

Ioana Drăgan classifies Omul muntelui (Man of the Mountain) as belonging to the adventures ("outlaw") fiction genre, because the "popular" hero par excellence, the local outlaw, both in the sense of a novel of this type and in folklore, embeds all the characteristics of the vigilante Rodolphe 3 or Monte Cristo4, to which is added the traditional "twinning" with nature. With a large audience, which recognizes the need for social justice, the outlaw from the popular novel of the nineteenth century therefore combines different common features, folklore characteristics and features elements specific to translations of English and American literature present in the Romanian space, the kind of adventures of Bob-Lee and Buffalo Bill in the "secular forest" and the "Wild West." Writings of this type in which several authors will specialize,

3 Protagonist of Les Mystères de Paris by Eugène Sue (Note by R.M).

4 Protagonist of Le Comte de Monte-Cristo by Alexandre Dumas (Note by R.M). 
such as the "Franco-Romanian" writer (Ştefan Cazimir); Marie Movilă in the 1860s; and especially after 1870 , N. D. Popescu in dozens of titles--Ilie Ighel-Deleanu, Panait Macri and Bucura Dumbravă are generally "adaptations" in prose of ballads or folk tales, to which all the props of the sensational novels of the time are knowingly applied.” (Drăgan 2002, 29)

\section{The short story Amelia Ştefănescu}

In 1883 , when V. A. Urechia published his Scrieri literare (Literary Works), in the first volume, in the chapter 'Notes' of "Literary Mosaics", the author tells about the piece of writing titled 'Femeia' ('The Woman') that was the outcome of the "unforgettable conversations with the late Mrs. Boucher".

She was an excellent governess and teacher, whom I saw three times a week at the institute of Mrs. Joye from Iaşi, where I also used to teach lessons. How many unforgettable souvenirs from those times! Poor Mlle Marie, where are you now, you who were my guide in the literary path, you who made me dream of happiness in the middle, the heaviest, and most tormented youth! ... do you remember our journey to Mountain Ceahlău, to Valea-vie, to Piatra, my illness during the trip, the storm at the top of the Pawn Point, the raft that we he brought to the Stone and which shattered the rocks; of tables tournantes with which we invoked the spirits with so much skill, such that we were convinced of their reality, of our kind students, among which I will never forget R. M. The so smart and passionate among beautiful and good!? ... No, I cannot remember the years I had you as a friend and advisor, without feeling a sweet tear in my eyes! ... Mlle Boucher wrote in collaboration, I can say, with me: Les Sept montagnes de Moldavie, published by me in Paris, with the pseudonym Maria Movilă; we also wrote short stories, Amelie Stefănesco, published in the newspapers, "Zimbrul şi Vulturul" ("The Bison and the Eagle"), and the later "Steaua Dunării ("The Danube Star"); Omul muntelui (Man of the Mountains), published in installments in the journal "Românul" ("The Romanian") and then in a separate brochure, etc., etc. The journal "Binele public" ("The Public Good") reproduced in 1881 Les Sept montagnes de Moldavie without knowing that most of these writings were written by V. A. Urechiă, Minister of Public Instruction! (Urechia 1976, 374)

Amelia Ştefănescu was launched as a column, first in the newspaper "Zimbrul şi Vulturul" ("The Bison and the Eagle"), (1858), which would later merge with the newspaper "Steaua Dunării ("The Danube Star"). The short

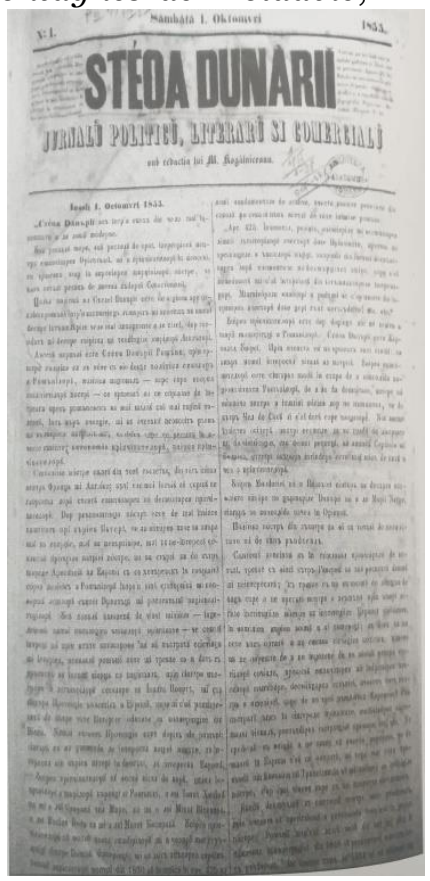


story has autobiographical accents. In it we also meet a French governess, but she will not be the protagonist, but her daughter, who falls in love with one of the sons of the Phanariot boyar who had hired her mother. After several unforeseen events, Amelia ends up in several hopeless situations, but Lady Maria L. chooses a happy ending for her writing.

Amelia Stefanesco, believes Ştefan Cazimir, describes the "morals of the nobility through the eyes of someone who had known them in detail. Family relationships in the aristocratic world are defined by dryness and conventionalism, hence real paternal or filial feelings are suppressed. Parents subject their children to a "forced hanging" and are content with the outward manifestation of respect, "without bothering to cultivate in their hearts the good germs that nature planted." (Cazimir 2006, 67)

\section{The novel Les Sept montagnes de Moldavie}

Les Sept montagnes de Moldavie (The Seven Mountains of Moldavia), published in France in 1863, is among the first novels to be published in France by a Franco-Romanian author. In the preface, Movilă directs readers to the poet Vasile Alecsandri's assertions of the bravery and strength to resist of the mountain peasants who governed themselves, creating real "republics of peasants, calm and hardworking," with their old customs. (Boucher 1863, 48-9) The story pits the main character, the great boyar Petre Ursachi, the reigning prince's messenger, against the inhabitants of a village located in a valley surrounded by seven mountains. The description of Uraschi Family refers to the portrait of the "ciocoi" (nouveau riche) present in several novels of the time: "a big stocky man with a treacherous smile, oblique approach" who believes that everything can be bought, even the heart of young Todora, priest Ioan's daughter, the spiritual leader of the village. His intention is to usurp the rights of the peasants, masters of these lands given to them by Stephen the Great as a reward after a battle won when he was helped by the seven sons of Vrâncioaia. They all settled a kind of republic ruled by a council of old men and in order to seize these lands he makes use of lawsuits and resorts to numerous intrigues to arrive at his purposes. Faced with the wisdom and skill of the răzeşi (the name for free Moldavian people who owned their lands in medieval times), the prince decided to resort to force. However, violence is useless, the mountain people succeed in thwarting all plans of the prince, and the story ends with the victory of the răzeşi who will continue their quiet life in their wild lands.

What do we notice about this first novel written by a woman? The epic speech does not go beyond the writing style of the early days of literature and the modern reader will spot an easy romanticism, exaggerated sentimentality, pathos, and artificiality in the style. The epic plot is constructed schematically on the opposition of good and evil, the 
characters are also ranged on both sides, the "good" being idealized, while the "bad" treated in very dark colors. Certain qualities of characterization are not lacking, however. An art of gradation renders the composition more solid. The meeting between priest Ioan and the reigning prince is performed with psychological finesse. The ability to realistically describe the social environment, customs of the time or to create true characters who do not lack local color represent another asset of this prose, such as the evocation of trial following which the peasants should have been despoiled. Published in France, this novel had to undergo French editorial constraints, as well as Romanian words, difficult to translate or untranslatable, which were spelled in French and very often explained by footnotes. Altogether, the portrait imagined by Ştefan Cazimir in his article highlights the qualities of the writer who, as a "modest and industrious worker in the field of literature, contributed, through her work in Romanian and French, to the struggle for progress and the emancipation of her adoptive homeland." (Cazimir 1961, 183)

*

We are perhaps closer to uncovering the true author of Omul muntelui and the short story Amelia Ştefănescu, both of them written in Romanian, and hopefully of Les Sept montagnes de Moldavie and Luopo, both of them written in French and published in Paris. The search continues, enriching the appreciation of Romanian writing of a century and a half ago, even if the certain answer remains elusive.

\section{References}

\section{Primary sources:}

Boucher, Marie (Doamna L.; Marie Movilă). Omul muntelui. Romançu [pe copertă: Romans] original de Doamna L. [= Marie Boucher]. Bucuresci (Impr. Ferdinand Om). (1857). [pe copertă: 1858]. (24 x 17). 132 p. Pe copertă: Imprimeria lui C. A. Rosetti. Autorul identificat după: Cazimir, p. 25, unde se menționează că romanul ar fi scris în colaborare cu V.A. Ureche.

Boucher, Marie. (1863). Les sept montagnes. Histoire moldave, par Marie Movilă [= Marie Boucher]. Paris, E. Dentu Éditeur-Libraire Libraire de la Société des gens de lettres (Alger, Impr. A. Molot et Cie). (19 x 13). VI1, 141 p. Lipsă coperta. Autorul identificat după: Cazimir, p. 25 unde se menționează că romanul ar fi scris în colaborare cu V. A. Ureche care s-a îngrijit de publicarea lui. Sapte munți, fragments published by the journal "Binele public" ("The Public Welfare"), III (1881).

Movilă, Marie. (1867). "Loupo", Revue Moderne, (1 et 2 livraisons, sur 5), Du $1^{\circ}$ juillet 1867 au $1^{\circ}$ septembre 1867 . Tome 42. P., au bureau, 1867 , in-8, demi-chagrin vert bronze, dos lisses ornés de filets et listels à froid, tr. mouch., rel. de l'ép., 632 pp. (C168). Cette dernière, qui serait roumaine, a aussi écrit sous les noms de 
Madame L. Et de Marie Boucher. Fragments published by the journal "Binele public" ("The Public Welfare"), 1878.

Movilă, Marie. (1867). "Loupo”, Revue Moderne, (3 et 4 livraisons, sur 5), Du $1^{\circ}$ octobre 1867 au $1^{\circ}$ décembre 1867 . Tome 43. P., au bureau, 1867, in-8, demi-chagrin vert bronze, dos lisses ornés de filets et listels à froid, tr. mouch., rel. de l'ép., 600 pp. (C168). Cette dernière, qui serait roumaine, a aussi écrit sous les noms de Madame L. Et de Marie Boucher. Fragments published by the journal "Binele public" (“The Public Welfare"), 1878.

Doamna L. (2013). Omul muntelui. Transcriere interpretativă de text chirilic manuscris, studiu introductiv, note şi comentarii de Ramona Mihăilă. Bucureşti: Editura Muzeul Literaturii Române.

Doamna Maria L. (2013). Amelia Ştefănescu. Culegere de text, transcriere interpretativă de text chirilic manuscris, studiu introductiv, note şi comentarii de Ramona Mihăilă. Bucureşti: Editura Muzeul Literaturii Române.

\section{Secondary sources}

Cazimir, Ştefan. (1961). "Scriitoarea franco-română Marie Boucher" ("The FrenchRomanian Woman Writer”), Analele Universităţii Bucureşti, Seria Ştiințe sociale, Filologie, anul X, nr. 23, 160-193.

Cazimir, Ştefan. (1956). "Misterul Doamnei L" ("Lady L’s Mystery”), Viața românească, no. 11.

Cazimir, Ştefan. (2006). Alfabetul de tranziție (The Transition Alphabet). Bucureşti: Humanitas.

Drăgan, Ioana. (2002). Romanul popular în România: Literar si paraliterar (The Mystery Novel in Romania: Literary and Non Fiction). Cluj Napoca: Editura Casa Cărții cu Ştiință.

Juncănaru Pedemonte, Emil. (2013). "Călători români şi străini pe Muntele Ceahlău” (Romanian and Foreign Travellers to the Ceahlău Mountain”), Lucrările simpozionului CEAHLAU Natură, istorie şi turism. Ediția a I-a Durău.

Manolescu, Nicolae. (1999). Arca lui Noe (Noa's Ark). Bucureşti: Editura Gramar.

Urechia, V.A. Scrieri literare (Literary Writing). Bucureşti: Minerva, 1976, p. 374.

*** (2006). Repertoriul traducătorilor români de limbă franceză, italiană, spaniolă (Repertoire of Romanian Translators of French, Italian, Spanish Language) (secolele al XVIII-lea si al XIX-lea) Studii de istorie a traducerii (I), Georgiana Lungu Badea (editor). Editura Universității de Vest, Timişoara.

*** (2004). Dicționarul cronologic al romanului românesc de la origini până la 1989 (The Chronological Dictionary of the Romanian Novel from its Origins until 1989), Ion Istrate et alii. Bucureşti, Editura Academiei Române.

*** (2004). History of the Literary Cultures of East-Central Europe: Junctures and Disjunctures in the 19th and 2oth Centuries. Volume IV: Types and Stereotypes, Marcel Corniş-Pope, John Neubauer (editors). John Benjamin Publishing Company.

\section{Supplementary sources}

Barbu, Marian. (1981). Romanul de mistere în literatură română (The Mystery Novel in Romanian Literature), Craiova: Editura Scrisul Românesc.

Călinescu, George. (1982). Istoria literaturii române de la origini până în prezent (The History of the Romanian Literature since Its Beginning to the Contemporary Times). Bucureşti: Editura Minerva. 
Cornea, Paul. (1966). De la Alecsandri la Eminescu (From Alecsandri to Eminescu). Bucureşti: Editura pentru Literatură.

Cosma, Anton. (1985). Geneza romanului românesc (The Genesis of the Romanian Novel). Bucureşti: Editura Univers.

Duică-Bogdan, Gheorghe. (1921). "V. Alecsandri şi Maria Movilă,": [o analiză a lucrării publicată în anul 1863 la Paris de V. Alecsandri Les sept montagne. Histoire moldave scrisă de Maria Movilă în care sunt evocate momente din istoria Vrancei] // Convorbiri literare. Anul 53, no. 10-11.

Goia, Vistian. (1978). V. A. Urechia. Bucureşti: Minerva.

Mihăilă, Ramona. (2012). "(In)Visible European Connecting Channels: Mapping Nineteenth Century Women's Writings," Journal of Research in Gender Studies, no. 1(1), 86-98.

Mihăilă, Ramona. (2011). "Challenging the Literary Scene: Late Nineteenth-Century Romanian Women Writers," Journal of Research in Gender Studies, no. 2(1), 124-134,

Păcurariu, D. (1959). "Un romancier necunoscut din veacul trecut," (“An Unknown Novelist in the Last Century") Viața Românească, XII.

Petrescu, Liviu. (1979). "Începuturile romanului românesc" ("The Beginning of the Romanian Novel”), Vatra Românească, XXXII, 11.

Piru, Alexandru. (1981). Istoria literaturii române de la început până azi (The History of the Romanian Literature since its Beginning to Present). Bucureşti, Editura Univers.

Piru, Alexandru. (1973). "O sută de ani de roman" ("One Hundred Years of Writing Novels”), Analize şi sinteze critice. Craiova, Editura Scrisul românesc.

Straje, Mihail. (1973). Dicționar de pseudonime, alonime, anagrame, asteronime, criptonime ale scrïtorilor şi publiciştilor români (The Dictionary of Pseudonyms, Allonyms, Anagrams, Asteronyms, Kryptonyms of Romanian Writers and Publicists). Bucureşti, Editura Minerva.

Vîrgolici, Teodor. (1963). Inceputurile romanului românesc (The Beginning of the Romanian Novel). Bucureşti, Editura pentru literatură.

Zamfir, Mihai. (1965). "Incercare asupra romanului românesc" ("About the Romanian Novel”), Limbă şi Literatură, vol. X, 169. 